\title{
KAJIAN KOMPETENSI DAN PROFESIONALISASI GURU
}

\author{
Lala Jelita Ananda \\ Surel : ljananda@unimed.ac.id
}

\begin{abstract}
This research was executed at SMK Sandhy Putra 2 Medan. The purpose of this research is to know how far the teacher's understanding of the competence of educators. Researchers use interviews and questionnaires to know the competence of professional teachers. Based on calculations, it is shown that the mean value of teacher competence data is 180.7 . With the lowest 168 and the highest 195 so that the range of data is 27 . Median data 182, the Modus is 182 and the standard deviation 8.0006. Based on these results concluded that the teacher still does not know what the legal basis of the implementation of education and essence
\end{abstract}

Key Words: Competence, Profesional, Teacher

\begin{abstract}
ABSTRAK
Penelitian ini dilakukan di SMK Sandhy Putra 2 Medan. Tujuan dari penelitian ini adalah untuk melihat sejauh mana pemahaman guru tentang kompetensi pendidik. Peneliti menggunakan wawancara dan angket untuk mengetahui kompetensi guru profesional. Berdasarkan data yang diperoleh, ditunjukkan bahwa nilai rata-rata dari data kompetensi guru adalah 180,7. Nilai terendah 168 dan nilai tertinggi 195 sehingga rentang data tersebut adalah 27. Nilai tengah data 182 , nilai modus adalah 182 serta standar deviasinya 8,0006. Berdasarkan hasil tersebut disimpulkan bahwa guru masih belum mengetahui apa saja landasan hukum pelaksanaan pendidikan dan esensinya.
\end{abstract}

Kata Kunci: Kompetensi, Profesional, Guru

\section{PENDAHULUAN}

Kurikulum, tenaga pendidik dan peserta didik merupakan tiga komponen penting dalam dunia pendidikan. Keberhasilan sebuah pendidikan dalam melahirkan generasi bangsa yang berkualitas bergantung pada berjalan tidaknya fungsi dan keterhubungan dari ketiga komponen tersebut. Keterpautan tiga komponen tersebut akan mengindikasikan kualitas luaran dari sistem pendidikan.

Pada dasarnya sistem pendidikan adalah mesin cetak yang akan membentuk mental generasi bangsa sebagai pemegang "tongkat estafet" di masa mendatang. Jika dibandingkan prestasi anak bangsa dengan dengan prestasi peserta didik di luar negeri, bangsa Indonesia masih sangat jauh tertinggal. Jika direnungi, penyebab dari kesenjangan ini adalah adanya masalah pada keterhubungan masing-masing fungsi dari ketiga komponen tersebut, yaitu kurikulum, pendidik, dan peserta didik.

Pada komponen tenaga pendidik, suatu langkah tepat yang 
pendidik, suatu langkah tepat yang dapat diambil adalah upaya pembekalan guru melalui pendidikan dan pelatihan, hal ini bertujuan dalam membentuk figur pendidik yang strategis dalam suatu sistem pendidikan. Pendidikan dan pelatihan ini hendaknya dilakukan secara intensif, terpadu, berkesinambungan, dan inovatif.

Sejalan dengan UndangUndang Republik Indonesia Nomor 14 Tahun 2005 Tentang Guru dan Dosen, terdapat 4 kompetensi yang harus dimiliki oleh seorang guru. Empat kompetensi tersebut meliputi kompetensi pedagogik, kompetensi kepribadian, kompetensi sosial, dan kompetensi profesional.

Hal ini sangat memerlukan perhatian khusus mengingat masih banyaknya guru yang belum memahami betul bagaimana implementasi dari keempat kompetensi tersebut. Disisi lain, bahwa begitu pentingnya peran figur seorang guru sebagai garda terdepan dalam upaya penyiapan moralitas generasi bangsa di masa mendatang.

Oleh karena itu, usaha pembekalan guru melalui berbagai kegiatan untuk mendukung profesionalitasnya sangat penting untuk dilakukan.

Usaha pengembangan profesionalitas guru sebaiknya dilakukan melalui kegiatan ilmiah yang sarat dengan pembekalan kompetensi guru dan pemahamannya terhadap kompetensi-kompetensi yang harus dimilikinya. Termasuk di dalamnya, upaya yang dilakukan oleh guru maupun pihak sekolah untuk meningkatkan keprofesionalan guru di sekolahnya.

\section{METODE PENELITIAN}

Penelitian ini dilakukan di SMK Sandhy Putra 2 Medan. Waktu Pelaksanaan penelitian ini adalah pada tanggal 01 s.d 06 Mei 2017. Subjek dalam penelitian ini adalah 10 orang guru yang mengajar di SMK Sandhy Putra 2 Medan.

Tahap-tahap yang dilakukan dalam penelitian ini adalah:

a. Tahap Awal

- Menyusun instrumen penelitian

- Menentukan lokasi dan waktu penelitian

- Meminta izin kepada pihak sekolah untuk mengadakan penelitian

- Menentukan sampel penelitian

b. Tahap Pelaksanaan Penelitian

- Memberikan angket kepada guru-guru.

- Menjelaskan cara pengisian angket.

- Melakukan wawancara dengan guru bersangkutan

c. Tahap Akhir Penelitian

- Menganalisis data yang telah diperoleh

- Menarik kesimpulan

Alat yang digunakan dalam mengumpulkan data penelitian ini adalah angket dan wawancara yang dilakukan pada guru. 
Adapun teknik analisis data yang dilakukan peneliti adalah sebagai berikut.

a. Paparan Data

Paparan data adalah proses penampilan data secara sederhana dalam tabel.

b. Penarikan kesimpulan

Penyimpulan data adalah proses pengambilan intisari dari data yang sudah terorganisasikan tersebut dalam bentuk pernyataan kalimat ataupun formula yang singkat dan padat tetapi mengandung pengertian luas. Penarikan kesimpulan untuk mengetahui apakah guru sudah menguasai 4 kompetensi yang wajib dimiliki oleh seorang guru.
HASIL PENELITIAN DAN PEMBAHASAN

Dalam penelitian ini, peneliti menggunakan wawancara secara langsung dan memberikan angket pada guru untuk mengetahui kompetensi guru profesional. Untuk memperoleh data tentang identifikasi kompetensi guru profesional, maka dilakukan wawancara oleh guru yang bersangkutan dan pengisian angket mengenai kompetensi pedagogik, kompetensi kepribadian, kompetensi sosial dan kompetensi profesional.

Data yang diperoleh dari lapangan untuk kompetensi guru adalah skor terendah 31 dan skor tertinggi adalah 50. Adapun distribusi frekuensi variabel kompetensi guru adalah sebagai berikut:

\section{Tabel distribusi frekuensi kompetensi guru}

\begin{tabular}{|c|c|c|}
\hline Interval & $\mathrm{F}$ & $\%$ \\
\hline $168-174$ & 3 & $30 \%$ \\
\hline $175-181$ & 1 & $10 \%$ \\
\hline $182-188$ & 4 & $20 \%$ \\
\hline $189-195$ & 2 & $20 \%$ \\
\hline Jumlah & $\mathbf{1 0}$ & $\mathbf{1 0 0} \%$ \\
\hline
\end{tabular}

Tabel data statistik distribusi frekuensi kompetensi guru

\begin{tabular}{|c|c|c|c|c|c|c|}
\hline Variabel & Mean & Median & Modus & $\begin{array}{c}\text { Nilai } \\
\text { Minimal }\end{array}$ & $\begin{array}{c}\text { Nilai } \\
\text { Maksimal }\end{array}$ & $\begin{array}{c}\text { Std. } \\
\text { Deviasi }\end{array}$ \\
\hline $\begin{array}{c}\text { Kompetensi } \\
\text { Guru }\end{array}$ & 180,7 & 182 & 182 & 168 & 195 & 8,0006 \\
\hline
\end{tabular}


Lala Jelita Ananda : Kajian Kompetensi dan ....

Berdasarkan perhitungan dengan program Microsoft Excel 2010 pada tabel di atas, ditunjukkan bahwa nilai mean atau rata-rata dari data kompetensi guru adalah 180,7. Dengan nilai terendah 168 dan nilai tertinggi 195 sehingga rentang data tersebut adalah 27. Median atau nilai tengah data 182 , nilai modus atau nilai dengan frekuensi terbanyaknya adalah 182 serta standar deviasinya 8,0006 .

Untuk mengkategorisasikan data menjadi tiga kategori maka dilakukan pencarian nilai ideal data sebagai berikut:

$$
\begin{aligned}
& \text { Mean Ideal }=\frac{1}{2}(\text { skor } \text { maks ideal }+ \text { skor min ideal })= \\
& \frac{1}{2}(200+40)=120 \\
& \text { Standar deviasi ideal }=\frac{1}{6}(\text { skor maks ideal }- \text { skor } \text { min ideal })= \\
& \frac{1}{6}(200-40)=26,667 \\
& \text { a }=\text { mean ideal }- \text { std deviasi ideal }=93,33 \\
& b=\text { mean ideal }- \text { std deviasi ideal }=146,67
\end{aligned}
$$

$$
\begin{array}{ll}
\text { - } & \text { Tinggi }=\mathrm{x} \geq \mathrm{b} \\
\text { - } & \text { Sedang }=\mathrm{a} \leq \mathrm{x} \leq \mathrm{b} \\
\text { - } & \text { Rendah }=\mathrm{x} \leq \mathrm{a}
\end{array}
$$


SEJ VOLUME 7 NO. 2 JUNI 2017

\begin{tabular}{|c|c|c|c|c|c|c|c|c|c|c|}
\hline \multirow[b]{2}{*}{ Pertanyaan ke- } & \multicolumn{10}{|c|}{ Responden } \\
\hline & A & B & C & D & $\mathbf{E}$ & $\mathbf{F}$ & G & $\mathbf{H}$ & I & J \\
\hline 1 & 5 & 5 & 5 & 5 & 5 & 5 & 5 & 5 & 5 & 5 \\
\hline 2 & 5 & 5 & 5 & 5 & 5 & 4 & 5 & 5 & 5 & 5 \\
\hline 3 & 5 & 5 & 4 & 5 & 4 & 5 & 5 & 5 & 5 & 5 \\
\hline 4 & 5 & 5 & 5 & 5 & 5 & 4 & 5 & 5 & 4 & 4 \\
\hline 5 & 5 & 5 & 4 & 0 & 4 & 5 & 5 & 5 & 4 & 4 \\
\hline 6 & 5 & 5 & 4 & 4 & 4 & 5 & 5 & 5 & 5 & 5 \\
\hline 7 & 5 & 5 & 5 & 5 & 5 & 5 & 4 & 5 & 5 & 5 \\
\hline 8 & 5 & 4 & 4 & 4 & 4 & 4 & 5 & 5 & 3 & 3 \\
\hline 9 & 5 & 5 & 4 & 5 & 4 & 4 & 4 & 5 & 3 & 3 \\
\hline 10 & 5 & 4 & 5 & 5 & 5 & 5 & 4 & 5 & 4 & 4 \\
\hline 11 & 4 & 4 & 4 & 4 & 4 & 4 & 3 & 1 & 4 & 4 \\
\hline 12 & 5 & 5 & 4 & 4 & 4 & 5 & 4 & 5 & 5 & 5 \\
\hline 13 & 5 & 5 & 4 & 4 & 4 & 5 & 4 & 5 & 4 & 4 \\
\hline 14 & 5 & 5 & 4 & 4 & 4 & 5 & 5 & 5 & 4 & 4 \\
\hline 15 & 5 & 5 & 5 & 5 & 5 & 5 & 4 & 5 & 4 & 4 \\
\hline 16 & 5 & 5 & 5 & 5 & 5 & 5 & 4 & 5 & 5 & 5 \\
\hline 17 & 5 & 5 & 5 & 5 & 5 & 5 & 5 & 5 & 5 & 5 \\
\hline 18 & 5 & 5 & 4 & 5 & 4 & 5 & 4 & 5 & 5 & 5 \\
\hline 19 & 5 & 4 & 5 & 4 & 5 & 4 & 4 & 5 & 5 & 5 \\
\hline 20 & 5 & 4 & 5 & 4 & 4 & 5 & 5 & 4 & 5 & 5 \\
\hline 21 & 5 & 5 & 5 & 5 & 5 & 4 & 4 & 5 & 5 & 5 \\
\hline 22 & 5 & 5 & 4 & 5 & 5 & 4 & 4 & 5 & 5 & 5 \\
\hline 23 & 5 & 5 & 5 & 5 & 5 & 5 & 4 & 5 & 5 & 5 \\
\hline 24 & 2 & 4 & 2 & 5 & 5 & 5 & 5 & 1 & 1 & 1 \\
\hline 25 & 5 & 4 & 5 & 4 & 4 & 5 & 4 & 5 & 5 & 5 \\
\hline 26 & 5 & 5 & 5 & 5 & 5 & 5 & 4 & 5 & 4 & 3 \\
\hline 27 & 5 & 5 & 5 & 4 & 4 & 5 & 3 & 5 & 5 & 5 \\
\hline 28 & 5 & 5 & 5 & 4 & 4 & 5 & 3 & 4 & 5 & 5 \\
\hline 29 & 5 & 4 & 4 & 3 & 4 & 5 & 3 & 5 & 3 & 3 \\
\hline 30 & 4 & 5 & 5 & 5 & 5 & 4 & 4 & 5 & 4 & 4 \\
\hline 31 & 5 & 5 & 5 & 5 & 5 & 5 & 4 & 5 & 4 & 4 \\
\hline 32 & 5 & 4 & 5 & 4 & 5 & 5 & 4 & 5 & 4 & 4 \\
\hline 33 & 5 & 5 & 5 & 5 & 5 & 5 & 5 & 5 & 4 & 4 \\
\hline 34 & 5 & 5 & 5 & 5 & 5 & 4 & 5 & 5 & 4 & 4 \\
\hline 35 & 5 & 5 & 4 & 5 & 4 & 4 & 5 & 5 & 5 & 5 \\
\hline 36 & 5 & 5 & 5 & 5 & 5 & 5 & 5 & 5 & 4 & 4 \\
\hline 37 & 5 & 5 & 4 & 4 & 5 & 4 & 4 & 5 & 4 & 4 \\
\hline 38 & 5 & 4 & 5 & 4 & 4 & 4 & 4 & 5 & 4 & 4 \\
\hline 39 & 5 & 4 & 4 & 3 & 5 & 3 & 1 & 1 & 3 & 4 \\
\hline 40 & 5 & 5 & 5 & 5 & 4 & 5 & 4 & 4 & 5 & 5 \\
\hline Jumlah & 195 & 189 & 182 & 177 & 182 & 185 & 168 & 185 & 172 & 172 \\
\hline
\end{tabular}

Tabel kategori kompetensi guru

\begin{tabular}{|c|c|c|c|}
\hline $\begin{array}{c}\text { Interval } \\
\text { kategori }\end{array}$ & $\mathrm{F}$ & $\%$ & Kategori \\
\hline $\mathrm{x} \geq \mathrm{b}$ & 10 & $100 \%$ & Tinggi \\
\hline $\mathrm{a} \leq \mathrm{x} \leq \mathrm{b}$ & 0 & $0 \%$ & Sedang \\
\hline $\mathrm{x} \leq \mathrm{a}$ & 0 & $0 \%$ & Rendah \\
\hline
\end{tabular}

$* \mathbf{x}=$ skor kompetensi guru 


\section{Pembahasan}

Hasil penelitian dari 10 responden di SMK Sandhy Putra 2 Medan berdasarkan kuesioner tertutup menunjukkan bahwa, guru memiliki ke empat kompetensi profesi guru yaitu kompetensi pedagogik, kompetensi kepribadian, kompetensi profesional dan kompetensi sosial. Meski begitu masih banyak guru yang merasa malu untuk berdiskusi dengan rekan kerja mengenai masalah pembelajaran di sekolah. Berdasarkan beberapa pertanyaan tambahan masih banyak guru yang tidak mengetahui apa saja landasan hukum yang digunakan dalam penyelenggaraan pendidikan dan beberapa guru tidak mengetahui isinya khusus UU No. 14 Tahun 2005. Untuk pertanyaan apa saja yang Bapak/Ibu ketahui tentang profesionalisasi guru yang ada di Indonesia kebanyakan menjawab "Guru harus memiliki kualifikasi akademik, kompetensi (pedagogik, kepribadian, profesional dan sosial).

Dalam profesionalisasi guru, sekolah menyediakan dan melengkapi sarana dan prasarana sekolah, merevisi materi pembelajaran, dan memberi pelatihan sesuai bidangnya kepada guru-guru. Pelatihan tersebut mencakup pelatihan yang diadakan langsung oleh pihak sekolah dan pihak luar seperti Dinas Pendidikan, Pariwisata dan lainnya, serta pelatihan yang diadakan oleh Yayasan Pendidikan Telkom seperti PLPG khusus sekolah yang bernaung di bawahnya, pelatihan komputer, pelatihan untuk guru produktif seperti micro TIK, digital marketing, penyusunan modul belajar, untuk kepala sekolah dilaksanakan budget committee, e-library, untuk pegawai ada bimbingan mental dan masih banyak lagi.

\section{SIMPULAN}

Berdasarkan hasil penelitian, dapat disimpulkan bahwa guru masih belum mengetahui apa saja landasan hukum pelaksanaan pendidikan dan esensinya. Meskipun begitu, guru mengetahui UU No. 14 Tahun 2005 Tentang Guru dan Dosen, yang menyatakan guru harus memiliki kualifikasi akademik, kompetensi yaitu kompetensi pedagogik, kepribadian, profesional dan sosial, memiliki sertifikat pendidik serta sehat jasmani dan rohani.

Guru-guru pengajar di SMK Sandhy Putra 2 Medan memiliki keempat kompetensi tersebut sehingga dapat dikatakan pembelajaran yang dilakukan di dalam kelas merupakan proses pembelajaran yang baik dan efektif. Sekolah ini berdiri di bawah naungan yayasan, yang melakukan banyak hal untuk meningkatkan kompetensi profesional guru. Kompetensi profesional dapat dikatakan sudah mencakup kompetensi lainnya. halhal lain yang dilakukan dalam peningkatan kompetensi guru adalah dengan menyediakan sarana dan prasarana sekolah yang baik, memberikan kesempatan bagi kepala sekolah, guru dan pegawai untuk 
melakukan pelatihan seperti budget committee khusus kepala sekolah, PLPG khusus dari sekolah, penyempurnaan modul belajar, micro TIK, digital marketing, bimbingan mental bagi para pegawai sekolah dan masih banyak lagi.

\section{DAFTAR RUJUKAN}

Alma, Buchari dkk. 2009. Guru Profesional. Bandung: Alfabeta

Arikunto, Suharsimi. 2006. Prosedur Penelitian: Suatu Pendekatan Praktik. Jakarta: Rineka Cipta
Uno, B, Hamzah. 2008. Profesi Kependidikan. Jakarta: Sinar Grafika Offse.

Damsar. 2011. Pengantar Sosiologi Pendidikan. Jakarta: Prenada Media.

Nurdin, Syafruddin. 2005. Guru Profesional. Ciputat: PT. Ciputat Press.

Yamin, Martinis. 2006. Sertifikasi Profesi Keguruan di Indonesia. Jakarta: Gaung Persada Press. 